\title{
A novel hydroxyfuroic acid compound as an insulin receptor activator structure and activity relationship of a prenylindole moiety to insulin receptor activation Henry J Tsai* ${ }^{* 1,2,3}$ and Shan-Yen Chou* $* 1,4$
}

\begin{abstract}
Address: ${ }^{1}$ Pharmaceutical R\&D Program, Development Center for Biotechnology, Hsi-Chih City 221, Taiwan, Republic of China, ${ }^{2}$ Department of Biological Science and Technology, China Medical University, Taichung City 404, Taiwan, Republic of China, ${ }^{3}$ Department of Health and Nutrition Biotechnology, Asia University, Taichung County 413, Taiwan, Republic of China and ${ }^{4}$ Taigen Biotechnology Co, Taipei 114, Taiwan, Republic of China

Email: Henry J Tsai* - henry_j_tsai@yahoo.com; Shan-Yen Chou - sychou@taigenbiotech.com.tw

* Corresponding author †Equal contributors
\end{abstract}

Published: 30 July 2009

Journal of Biomedical Science 2009, 16:68 doi:10.1186/1423-0127-16-68

This article is available from: http://www.jbiomedsci.com/content/16/I/68

(c) 2009 Tsai and Chou; licensee BioMed Central Ltd.

This is an Open Access article distributed under the terms of the Creative Commons Attribution License (http://creativecommons.org/licenses/by/2.0), which permits unrestricted use, distribution, and reproduction in any medium, provided the original work is properly cited.
Received: 25 June 2008

Accepted: 30 July 2009

\begin{abstract}
Background: Diabetes Mellitus is a chronic disease and many patients of which require frequent subcutaneous insulin injection to maintain proper blood glucose levels. Due to the inconvenience of insulin administration, an orally active insulin replacement has long been a prime target for many pharmaceutical companies. Demethylasterriquinone (DMAQ) BI, extracted from tropical fungus, Pseudomassaria sp., has been reported to be an orally effective agent at lowering circulating glucose levels in diabetic $(\mathrm{db} / \mathrm{db})$ mice; however, the cytotoxicity associated with the quinone moiety has not been addressed thus far.

Methods: A series of hydroxyfuroic acid compounds were synthesized and tested for their efficacies at activating human insulin receptor. Cytotoxicity to Chinese hamster ovary cells, selectivities over insulin-like growth factor-I (IGF-I), epidermal growth factor (EGF), and fibroblast growth factor (FGF) receptors were examined in this study.

Result and Conclusion: This study reports a new non-quinone DMAQ BI derivative, a hydroxyfuroic acid compound (D-410639), which is 128 fold less cytotoxic as DMAQ BI and as potent as compound 2, a DMAQ BI synthetic derivative from Merck, at activating human insulin receptor. D-4I0639 has little activation potential on IGF-I receptor but is a moderate inhibitor to EGF receptor. Structure and activity relationship of the prenylindole moiety to insulin receptor activation is discussed.
\end{abstract}

\section{Background}

Diabetes mellitus is a chronic disease characteristic of elevated blood glucose concentrations with poor glucose utilization and homeostasis [1]. About $10 \%$ of all diabetic patients are type 1 insulin dependent diabetes mellitus (IDDM) in which insulin secreting $\beta$-islets of Langerhans are damaged or destroyed by aberrant $\mathrm{T}$ cells [2]. Other diabetes cases (about 90\%) are type 2 non-insulin dependent diabetes mellitus (NIDDM) that is proceeded by insulin resistance and frequently with metabolic syndrome [1]. For type 1 and late stage type 2 diabetic patients, a common method of alleviating hyperglycemia is by subcutaneous administration of exogenous insulin before each meal $[1,2]$. Due to the inconvenience of insu- 
lin administration, it has long been a primary goal of many pharmaceutical companies to develop an orally active therapeutic agent for treating hyperglycemia in diabetic patients.

Current diabetes therapies with orally active agents fall into five major classes, which are i) biguanide (metformin) that activates AMP-activated protein kinase (AMPK) [3-6]; ii) sulfonylurea as an insulin secretogue [79]; iii) peroxisome proliferator activated receptor (PPAR) $\gamma$-subtype activators [10-12]; iv) $\alpha$-glucosidase inhibitors $[13,14]$; v) dipeptidyl peptidase IV (DP-4) inhibitors [1518]. In addition to these targets, the insulin receptor activator is particularly interesting, because it may activate the insulin signal transduction pathway directly without the need of insulin, and yet it is small enough to be orally active. Extracted from tropical fungus, Pseudomassaria sp., demethylasterriquinone (DMAQ) B1 is one such compound [19-24] and has been shown to lower blood glucose in $d b / d b$ mice by activating insulin receptor's tyrosine kinase directly $[19,22]$. The compound was later modified to phenylindolyldihydroxyquinone (compound 2, by Merck's nomenclature), with an improved efficacy ( $\mathrm{EC}_{50}$ from $5.0 \mu \mathrm{M}$ to $0.3 \mu \mathrm{M})[20,21]$. However, DMAQ B1 and compound 2 each has a hydroxyquinone moiety that may facilitate free radical generation when in contact with high energy electrons [25]. Therefore, a new insulin receptor activator without a quinone moiety is a logical compound to develop.

It has been reported that DMAQ B1 can be converted to bisindolylhydroxyfuroic acids by biotransformation and thus replaces its quinone with a furoic acid moiety (Fig. 1), but still retains its insulin receptor activation potential [Chen et al. US Patent 6596760, 2003]. While through medicinal chemistry, prenylindole and isoprenylindole moieties on DMAQ B1 can be simplified to an indolyl and a phenyl moieties resulting a phenylindolyldihydroxyquinone (compound 2, Fig. 1) with an improved efficacy $[20,21]$. Combining these two features together, phenylindolylfuroic acid derivatives were synthesized [26], but for unknown reasons these compounds showed no observable insulin receptor activation efficacy (data not shown). Therefore, these phenylindolylfuroic acid derivatives were not pursued further, and the bisindolylfuroic acid scaffold is retained for further derivative development because of its absence of a quinone moiety. The isoprenyl chain on the isoprenylindole is not essential for the insulin receptor activation in our setting, and was omitted in subsequent derivatives (Fig. 1). A new class of insulin receptor activators was discovered under such circumstances. We report a new hydroxyfuroic acid compound, D-410639, that possesses insulin receptor activation property as well as inhibition for epidermal growth factor receptor (EGF-R/ErbB1).

\section{Methods}

\section{Materials and Chemicals}

The CHO cell line overexpressing recombinant human insulin receptor was kindly provided by Dr. Richard Roth at Stanford University. Scintillation cocktail and $\gamma-\mathrm{P}^{33}$ ATP were purchased from Perkin-Elmer (Wellesley, MA). P81 phosphocellulose paper is a product of Millipore (Billerica, MA). Ab-3 antibody is a product of Upstate (Charlottesville, VA). Recombinant human IGF-1 receptor, EGF-R (ErbB1), and FGF-R3 were purchased from R\&D systems (Minneapolis, MN). DMAQ B1 and Compound 2 of Merck were obtained from Calbiochem (La Jolla, CA). Other chemicals were purchased from Sigma-Aldrich (St. Louis, MO).

\section{Syntheses of Hydroxyfuroic Acid Compounds}

The synthesis strategy of hydroxyfuroic acids is summarized and presented in Fig. 2, as described below.

\section{Furan diester 3}

A $615 \mathrm{~mL}$ of benzene solution containing $170 \mathrm{mmol}$ dimethyl diglycolate 1 and $230 \mathrm{mmol}$ indolylglyloxalate 2 was added drop wise to a $720 \mathrm{~mL}$ of refluxing benzene suspension containing $t$ - $\mathrm{BuOK}$, prepared from dissolving potassium (4.5 molar eqs $v s$ ) in $765 \mathrm{mmol} t$ - $\mathrm{BuOH}$. After $2.5 \mathrm{~h}$, the cooled mixture was acidified and then 500 $\mathrm{mL}$ of ethyl acetate was added while under stirring. The organic layer was separated, concentrated, added with $1550 \mathrm{~mL}$ of DMF, and then treated with MeI (572 mmol) and $\mathrm{K}_{2} \mathrm{CO}_{3}(770 \mathrm{mmol})$. After $21 \mathrm{~h}$ of stirring, residues in the mixture was filtered off and the filtrate was evaporated under reduced pressure, followed by partitioning with $\mathrm{CH}_{2} \mathrm{Cl}_{2} / \mathrm{H}_{2} \mathrm{O}$. The separated organic layer was condensed and the residue was purified by chromatography on a silica gel to yield 3 (76.5 mmol, 45\%).

\section{Furan diester 4}

Fifty-seven mmol of 3 and $110 \mathrm{mmol}$ of DDQ was mixed in $813 \mathrm{~mL}$ of $\mathrm{CH}_{2} \mathrm{Cl}_{2} / \mathrm{H}_{2} \mathrm{O}(18: 1, \mathrm{v} / \mathrm{v})$ and stirred at room temperature for $21 \mathrm{~h}$. The resulting mixture was quenched with $5 \%$ aqueous $\mathrm{Na}_{2} \mathrm{CO}_{3}$, followed by partitioning with $\mathrm{CH}_{2} \mathrm{Cl}_{2} / \mathrm{H}_{2} \mathrm{O}$. The separated organic layer was condensed and the residue was purified by silica gel chromatography to yield 4 (34.2 $\mathrm{mmol}, 60 \%)$.

\section{Furan diester 5}

A $460 \mathrm{~mL}$ 2-butanone solution containing $46 \mathrm{mmol} 4$ was treated with $\mathrm{TsCl}(92 \mathrm{mmol})$ and $\mathrm{K}_{2} \mathrm{CO}_{3}(137 \mathrm{mmol})$. After $2 \mathrm{~h}$ refluxing, additional $46 \mathrm{mmol} \mathrm{TsCl}$ and 69 mmol $\mathrm{K}_{2} \mathrm{CO}_{3}$ were added and refluxed further overnight. The mixture was filtered and the filtrate was evaporated to leave a solidified residue. The residue was triturated over methanol to form a white powder suspension. The powder was isolated by filtration and dried to give 5 (42.3 mmol, 92\%). Alternatively, 5 can be prepared by metal- 


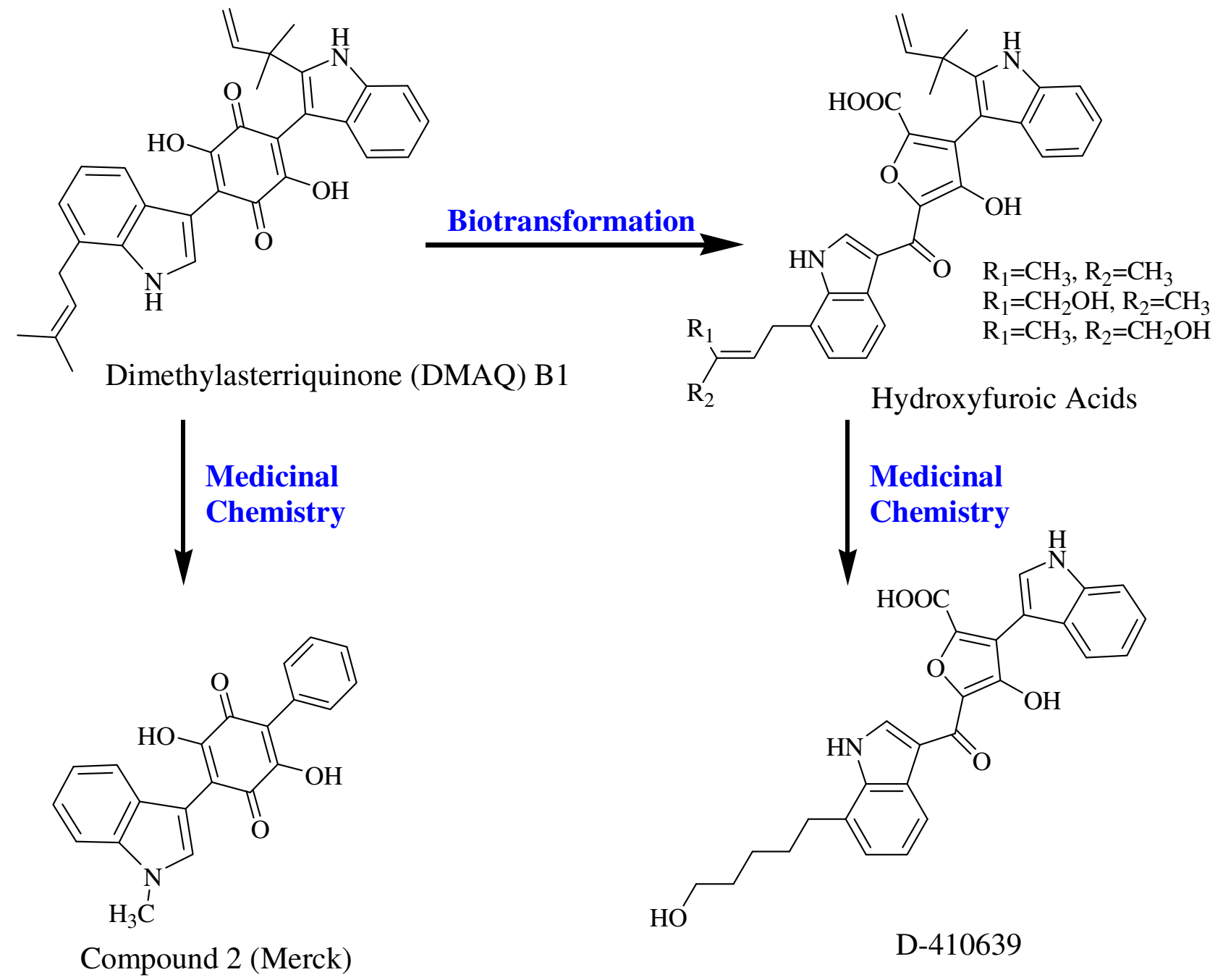

Figure I

Active receptor tyrosine kinase activators. Demethylasterriquinone $\mathrm{BI}$ is extracted from tropical fungus, Pseudomassaria sp., and can be transformed to hydroxyfuroic acid which still retains insulin receptor activation capability. Compound 2 and D410639 are derived from Demethylasterriquinone BI and hydroxyfuroic acid, respectively.

catalyzed cross coupling of triflorosulfonated $\mathbf{6}$ and an $\mathrm{N}$ tosyl-3-iodoindole derived boric acid 7 (1.5 molar eqs) in refluxing THF $(20 \mathrm{~mL} / \mathrm{g})$ which had a $66 \%$ yield.

\section{Furan diacid 8}

A solution containing $25.4 \mathrm{mmol}$ of 5 in $280 \mathrm{~mL}$ methanol and $23 \mathrm{~mL} \mathrm{H}_{2} \mathrm{O}$ was added with $177.7 \mathrm{mmol}$ of lithium hydroxide at $25^{\circ} \mathrm{C}$ and stirred for $5 \mathrm{~h}$. The mixture was acidified with $3 \mathrm{~N} \mathrm{HCl}$, followed by evaporation. The residue was extracted with ethyl acetate and washed with $\mathrm{H}_{2} \mathrm{O}$. The separated organic layer was evaporated to give 8 (25.2 mmol, 99\%).

\section{Furan halfester 9}

Methyl chloroformate $(22.0 \mathrm{mmol})$ predissolved in 30 $\mathrm{mL}$ dichloromethane was added to a $100 \mathrm{~mL}$ dichloromethane solution containing $22.0 \mathrm{mmol}$ of 8 and 23.1 mmol of triethylamine at $0^{\circ} \mathrm{C}$. After $1 \mathrm{~h}$ stirring at $0^{\circ} \mathrm{C}$, DMAP (2.6 mmol) was added and stirred at $0^{\circ} \mathrm{C}$ for $1 \mathrm{~h}$ and $18 \mathrm{~h}$ at room temperature. The resulting solution was then acidified, extracted with dichloromethane, and solvent evaporated. The residue was purified by silica gel chromatography to yield 9 (13.2 mmol, 60\%). 


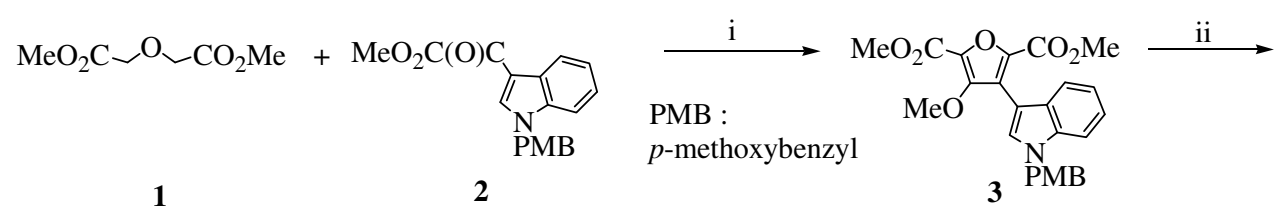

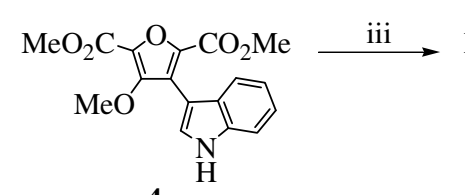

4

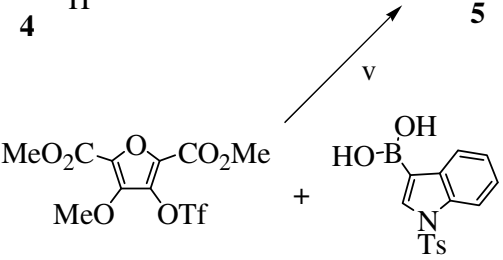

6

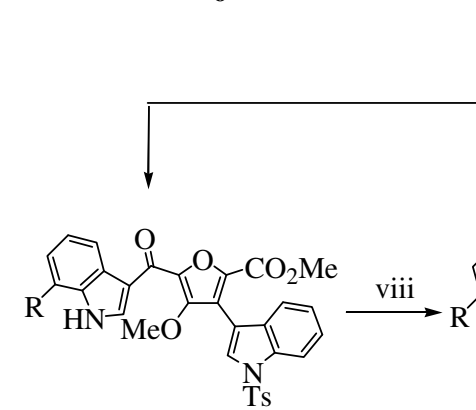

11

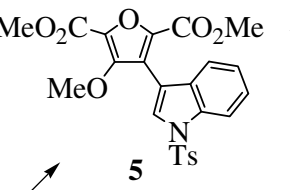

7
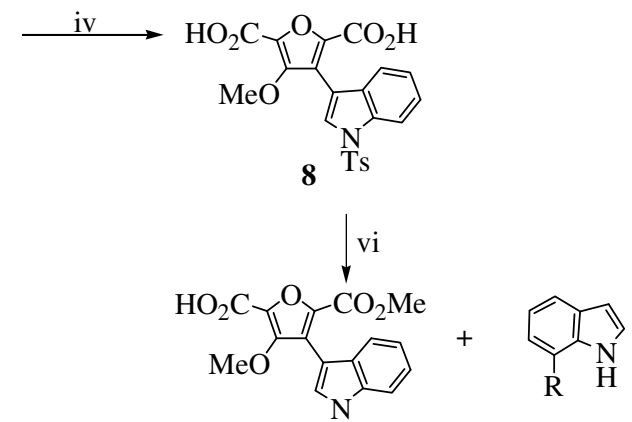

9

10

$$
\begin{aligned}
& \mathrm{R}=-\left(\mathrm{CH}_{2}\right)_{\mathrm{n}} \mathrm{OAc}, \mathrm{n}=3-5 \\
& \mathrm{R}=-\left(\mathrm{CH}_{2}\right)_{4} \mathrm{CH}_{4} \\
& \mathrm{R}=-\left(\mathrm{CH}_{2}\right)_{3} \mathrm{CH}\left(\mathrm{CH}_{2} \mathrm{OAc}\right)_{2} \\
& \mathrm{R}=-\left(\mathrm{CH}_{2}\right)_{\mathrm{n}} \mathrm{CO}_{2} \mathrm{Me}, \\
& \quad \mathrm{n}=2 \text { or } 4
\end{aligned}
$$

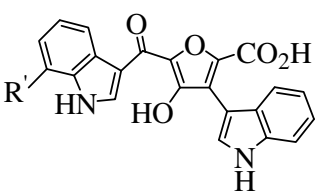

12

$$
\begin{aligned}
\mathrm{R}^{\prime}= & -\left(\mathrm{CH}_{2}\right)_{\mathrm{n}} \mathrm{OH}, \mathrm{n}=3, \mathrm{D}-410637 ; \\
& \mathrm{n}=4, \mathrm{D}-410638 ; \mathrm{n}=5, \mathrm{D}-410639 \\
\mathrm{R}^{\prime}= & -\left(\mathrm{CH}_{2}\right)_{4} \mathrm{CH}_{3}, \mathrm{D}-410641 \\
\mathrm{R}^{\prime}= & -\left(\mathrm{CH}_{2}\right)_{3} \mathrm{CH}\left(\mathrm{CH}_{2} \mathrm{OH}\right)_{2}, \mathrm{D}-410642 \\
\mathrm{R}^{\prime}= & -\left(\mathrm{CH}_{2}\right)_{\mathrm{n}} \mathrm{CO}_{2} \mathrm{H}, \mathrm{n}=4, \mathrm{D}-410643 ; \\
& \mathrm{n}=2, \mathrm{D}-410644
\end{aligned}
$$

\section{Figure 2}

Preparation of bisindolylhydroxyfuroic acids. i. a) K, $t-\mathrm{BuOH}$, benzene; b) Mel, N,N-dimethylformamide (DMF), 45\% (two steps); ii. DDQ, $\mathrm{CH}_{2} \mathrm{Cl}_{2} / \mathrm{H}_{2} \mathrm{O}$ (I8/I, v/v); $46 \%$; iii. TsCl, 2-butanone, $\mathrm{K}_{2} \mathrm{CO}_{3}$, reflux, $86 \%$; iv. $\mathrm{OH}-\mathrm{MeOH}, \mathrm{H}_{2} \mathrm{O}, 95 \%$; v. $\mathrm{PdCl}_{2}$ $\left(\mathrm{PPh}_{3}\right)_{2}(0.1 \mathrm{eq}), \mathrm{Na}_{2} \mathrm{CO}_{3}(3.0 \mathrm{eq}), \mathrm{DMF}, 90^{\circ} \mathrm{C}, 12 \mathrm{~h}, 66 \%$; vi. ClCO $\mathrm{Ce}_{2}(100 \mathrm{~mol} \%), \mathrm{NEt}_{3}(107 \mathrm{~mol} \%), \mathrm{CH}_{2} \mathrm{Cl}_{2}(6 \mathrm{~mL} / \mathrm{mmol} 8)$, DMAP ( 12 mol \%), $60 \%$; vii. a) oxalyl chloride, DMAP (cat.), r.t.; b) 7-substituted indole $10, \mathrm{Et}_{2} \mathrm{AlCl} \mathrm{CHCl}_{3}, 5166 \% ;$ viii. $^{\mathrm{BCl}}{ }_{3}$, $\mathrm{CH}_{2} \mathrm{Cl}_{2}, 0^{\circ} \mathrm{C}$ r.t.; $8085 \%$; ix. $5 \% \mathrm{NaOH}$ in methanol, reflux, $6670 \%$.

\section{Furan bisiindoles II}

Oxalyl chloride $(10 \mathrm{~mL} / \mathrm{g})$ was added to $9(12.2 \mathrm{mmol})$ and stirred for 20 minutes. The mixture was condensed under vacuum to give the acyl chloride of 9 . In a separated flask, a $60 \mathrm{~mL}$ dichloromethane solution containing 12.4 mmol of the 7 '-substituted indoles 10 was added with $\mathrm{Et}_{2} \mathrm{AlCl}$ ( $1 \mathrm{M}$ in hexane, $30 \mathrm{mmol}$ ) at $0^{\circ} \mathrm{C}$ and stirred for $0.5 \mathrm{~h}$ before $50 \mathrm{~mL}$ dichloromethane solution containing the aforementioned acyl chloride 9 was added. After $1 \mathrm{~h}$ stirring at $0^{\circ} \mathrm{C}$ and $14 \mathrm{~h}$ at room temperature, the reaction was quenched with $3 \mathrm{~N} \mathrm{HCl}$. The separated organic layer was condensed and the residue was purified by silica gel chromatography to yield 11 (5166\% yield). 


\section{Furan bisindoles 12}

A $50 \mathrm{~mL}$ dichloromethane solution containing $5.3 \mathrm{mmol}$ 4 was added with $\mathrm{BCl}_{3}$ ( $1 \mathrm{M}$ in hexane, $35 \mathrm{mmol}$ ) at $0^{\circ} \mathrm{C}$. The reaction mixture was stirred at $0^{\circ} \mathrm{C}$ for $0.5 \mathrm{~h}$ and at room temperature for $3 \mathrm{~h}$, and then diluted with additional $200 \mathrm{~mL}$ dichloromethane. After another $0.5 \mathrm{~h}$ stirring, the mixture was quenched on ice water and the separated organic layer was condensed. The residue was purified by silica gel chromatography and yielded 12 (8085\% yield).

\section{Bisindolylhydroxyfuroic acids (D-4 I0637D-4l0639 and D- 4 I064 ID-4 I0644)}

A methanol solution $(1015 \mathrm{~mL} / \mathrm{g})$ containing $0.11 \mathrm{~g}$ of 12 was added with $1.0 \mathrm{~mL}$ of $5 \%$ aqueous $\mathrm{NaOH}$ and refluxed for $0.5 \mathrm{~h}$. The mixture was concentrated, acidified with $3 \mathrm{~N} \mathrm{HCl}$, and then extracted with ethyl acetate. The extract was washed with brine, dried, and solvent evaporated. The residue was purified by silica gel chromatography to give the titled compounds with $6670 \%$ yield.

\section{Bisindolylhydroxythiophene carboxylic acid (D-4 I0640)}

The compound was obtained with $9.5 \%$ overall yield by applying the same methods described in furoic acid derivative (D-410639) but using thiodiglycolic acid dimethyl ester and 2 as the starting materials.

Physical properties of bisindolylhydroxyfuroic acid compounds are listed as following:

$\mathrm{D}-410637$, a yellow powder, $\mathrm{mp} 140142^{\circ} \mathrm{C}$ (ethyl acetate); ${ }^{1} \mathrm{H}-\mathrm{NMR}\left(500 \mathrm{MHz},{ }^{6} \mathrm{~d}-\mathrm{DMSO}\right) \delta: 1.841 .88(\mathrm{~m}$, $2 \mathrm{H}), 2.95(\mathrm{t}, \mathrm{J}=7.4 \mathrm{~Hz}, 2 \mathrm{H}), 3.51(\mathrm{t}, \mathrm{J}=6.5 \mathrm{~Hz}, 2 \mathrm{H})$, $7.027 .05(\mathrm{~m}, 1 \mathrm{H}), 7.117 .15(\mathrm{~m}, 2 \mathrm{H}), 7.187 .21(\mathrm{~m}, 1 \mathrm{H})$, $7.46(\mathrm{~d}, \mathrm{~J}=8.0 \mathrm{~Hz}, 1 \mathrm{H}), 7.50(\mathrm{~d}, \mathrm{~J}=8.0 \mathrm{~Hz}, 1 \mathrm{H}), 7.627 .63$ $(\mathrm{m}, 1 \mathrm{H}), 8.27(\mathrm{~d}, \mathrm{~J}=7.5 \mathrm{~Hz}, 1 \mathrm{H}), 8.66(\mathrm{~d}, \mathrm{~J}=2.2 \mathrm{~Hz}, 1 \mathrm{H})$. Mass spectrometry (MS) (ESI, negative mode): $443.2\left(\mathrm{M}^{+-}\right.$ $\mathrm{H})$; high resolution mass spectrometry (HREIMS): Calculated for $\mathrm{C}_{25} \mathrm{H}_{20} \mathrm{~N}_{2} \mathrm{O}_{6}\left(\mathrm{M}^{+}\right)$444.4361, found 444.4358.

$\mathrm{D}-410638$, a yellow powder, $\mathrm{mp} 145147^{\circ} \mathrm{C}$ (ethyl acetate); ${ }^{1} \mathrm{H}-\mathrm{NMR}\left(500 \mathrm{MHz},{ }^{6} \mathrm{~d}\right.$-acetone) $\delta: 1.631 .65(\mathrm{~m}$, $2 \mathrm{H}), 1.841 .86(\mathrm{~m}, 2 \mathrm{H}), 3.01(\mathrm{t}, \mathrm{J}=7.5 \mathrm{~Hz}, 2 \mathrm{H}), 3.64(\mathrm{t}, \mathrm{J}$ $=6.5 \mathrm{~Hz}, 2 \mathrm{H}), 7.077 .08(\mathrm{~m}, 1 \mathrm{H}), 7.157 .17(\mathrm{~m}, 2 \mathrm{H})$, $7.237 .25(\mathrm{~m}, 1 \mathrm{H}), 7.68(\mathrm{~d}, \mathrm{~J}=8.0 \mathrm{~Hz}, 1 \mathrm{H}), 7.357 .36(\mathrm{~m}$, $1 \mathrm{H}), 7.48(\mathrm{~d}, \mathrm{~J}=8.0 \mathrm{~Hz}, 1 \mathrm{H}), 7.7980(\mathrm{~m}, 1 \mathrm{H}), 8.35(\mathrm{~d}, \mathrm{~J}$ $=8.0 \mathrm{~Hz}, 1 \mathrm{H}), 8.60($ br s, $1 \mathrm{H}), 8.90(\mathrm{br} \mathrm{s}, 1 \mathrm{H}) . \mathrm{MS}(\mathrm{ESI}$, negative mode): $457.2\left(\mathrm{M}^{+}-\mathrm{H}\right)$; HREIMS: Calculated for $\mathrm{C}_{26} \mathrm{H}_{22} \mathrm{~N}_{2} \mathrm{O}_{6}\left(\mathrm{M}^{+}\right)$458.1478, found 458.1459.

$\mathrm{D}-410639$, a yellow powder, $\mathrm{mp} 158160^{\circ} \mathrm{C}$ (ethyl acetate); ${ }^{1} \mathrm{H}-\mathrm{NMR}\left(500 \mathrm{MHz},{ }^{6} \mathrm{~d}\right.$-acetone) $\delta: 1.531 .55(\mathrm{~m}$, $2 \mathrm{H}), 1.61(\mathrm{t}, \mathrm{J}=7.2 \mathrm{~Hz}, 2 \mathrm{H}), 1.82(\mathrm{t}, \mathrm{J}=7.4 \mathrm{~Hz}, 2 \mathrm{H}), 3.01$ $(\mathrm{t}, \mathrm{J}=7.8 \mathrm{~Hz}, 2 \mathrm{H}), 3.58(\mathrm{t}, \mathrm{J}=6.2 \mathrm{~Hz}, 2 \mathrm{H}), 7.107 .11(\mathrm{~m}$, $1 \mathrm{H}), 7.187 .20(\mathrm{~m}, 2 \mathrm{H}), 7.267 .28(\mathrm{~m}, 1 \mathrm{H}), 7.51(\mathrm{~d}, \mathrm{~J}=8.0$
$\mathrm{Hz}, 1 \mathrm{H}), 7.69(\mathrm{~d}, \mathrm{~J}=8.0 \mathrm{~Hz}, 1 \mathrm{H}), 7.79(\mathrm{~d}, \mathrm{~J}=2.5 \mathrm{~Hz}, 1 \mathrm{H})$, 8.38 (d, J = 7.9 Hz, 1H), 8.84 (d, J = 3.2 Hz, 1H), 10.7 (br s, $1 \mathrm{H}), 11.4$ (br s, $1 \mathrm{H})$. MS (ESI): $473.0\left(\mathrm{M}^{+}+\mathrm{H}\right)$; HREIMS: Calculated for $\mathrm{C}_{27} \mathrm{H}_{24} \mathrm{~N}_{2} \mathrm{O}_{6}\left(\mathrm{M}^{+}\right)$472.1634, found 472.1639.

$\mathrm{D}-410640$, a yellow powder, $\mathrm{mp} 144146^{\circ} \mathrm{C}$ (ethyl acetate); ${ }^{1} \mathrm{H}-\mathrm{NMR}\left({ }^{6} \mathrm{~d}-\mathrm{DMSO}\right) \delta: 1.391 .40(\mathrm{~m}, 2 \mathrm{H}), 1.471 .49$ $(\mathrm{m}, 2 \mathrm{H}), 1.661 .69(\mathrm{~m}, 2 \mathrm{H}), 2.91(\mathrm{t}, \mathrm{J}=7.6 \mathrm{~Hz}, 2 \mathrm{H}), 3.39$ $(\mathrm{t}, \mathrm{J}=7.1 \mathrm{~Hz}, 2 \mathrm{H}), 6.956 .98(\mathrm{~m}, 1 \mathrm{H}), 7.067 .10(\mathrm{~m}, 2 \mathrm{H})$, $7.157 .18(\mathrm{~m}, 1 \mathrm{H}), 7.397 .43(\mathrm{~m}, 2 \mathrm{H}), 7.52(\mathrm{~s}, 1 \mathrm{H}), 8.13$ $(\mathrm{d}, \mathrm{J}=7.9 \mathrm{~Hz}, 1 \mathrm{H}), 8.41(\mathrm{~s}, 1 \mathrm{H}), 11.2$ (br s, $1 \mathrm{H}), 12.4(\mathrm{br}$ s, $1 \mathrm{H}), 13.2$ (br s, $1 \mathrm{H})$. MS (ESI): $489.0\left(\mathrm{M}^{+}+\mathrm{H}\right)$; HREIMS: Calculated for $\mathrm{C}_{27} \mathrm{H}_{24} \mathrm{~N}_{2} \mathrm{O}_{5} \mathrm{~S}\left(\mathrm{M}^{+}\right)$488.1406, found 488.1421.

D-410641, an amorphous oil; ${ }^{1} \mathrm{H}-\mathrm{NMR}\left({ }^{4} \mathrm{~d}-\mathrm{MeOH}\right) \delta$ : 0.90 (m, 3H), 1.39 (br s, 4H), 1.73 (br s, 2H), 2.90 (br s, 2H), $7.04(\mathrm{~m}, 2 \mathrm{H}), 7.11(\mathrm{~m}, 1 \mathrm{H}), 7.17(\mathrm{~m}, 1 \mathrm{H}), 7.39(\mathrm{~d}$, $\mathrm{J}=8.11 \mathrm{H}), 7.59(\mathrm{~d}, \mathrm{~J}=8.7,2 \mathrm{H}), 8.28(\mathrm{~d}, \mathrm{~J}=7.8 \mathrm{~Hz}, 1 \mathrm{H})$, 8.86 (br s, $1 \mathrm{H})$. MS (ESI): $457.0\left(\mathrm{M}^{+}+\mathrm{H}\right)$; HREIMS: Calculated for $\mathrm{C}_{27} \mathrm{H}_{24} \mathrm{~N}_{2} \mathrm{O}_{5}\left(\mathrm{M}^{+}\right)$456.1685, found 456.1693.

$\mathrm{D}-410642$, a yellow powder, $\mathrm{mp} 141143^{\circ} \mathrm{C}$ (ethyl acetate); ${ }^{1} \mathrm{H}-\mathrm{NMR}\left(500 \mathrm{MHz},{ }^{6} \mathrm{~d}\right.$-acetone) $\delta: 1.501 .53(\mathrm{~m}$, $2 \mathrm{H}), 1.741 .76(\mathrm{~m}, 1 \mathrm{H}), 1.851 .89(\mathrm{~m}, 2 \mathrm{H}), 3.01(\mathrm{t}, \mathrm{J}=7.9$ $\mathrm{Hz}, 2 \mathrm{H}), 3.633 .67(\mathrm{~m}, 4 \mathrm{H}), 7.097 .12(\mathrm{~m}, 1 \mathrm{H}), 7.177 .21$ $(\mathrm{m}, 2 \mathrm{H}), 7.257 .28(\mathrm{~m}, 1 \mathrm{H}), 7.51(\mathrm{~d}, \mathrm{~J}=8.1 \mathrm{~Hz}, 1 \mathrm{H}), 7.68$ $(\mathrm{d}, \mathrm{J}=8.0 \mathrm{~Hz}, 1 \mathrm{H}), 7.79(\mathrm{~d}, \mathrm{~J}=2.6 \mathrm{~Hz}, 1 \mathrm{H}), 8.38(\mathrm{~d}, \mathrm{~J}=$ $7.8 \mathrm{~Hz}, 1 \mathrm{H}), 8.84(\mathrm{~d}, \mathrm{~J}=3.1 \mathrm{~Hz}, 1 \mathrm{H}), 10.68$ (br s, 1H),11.52 (br s, 1H). MS (ESI): $503.0\left(\mathrm{M}^{+}+\mathrm{H}\right)$; HREIMS: Calculated for $\mathrm{C}_{28} \mathrm{H}_{26} \mathrm{~N}_{2} \mathrm{O}_{7}\left(\mathrm{M}^{+}\right)$502.1740, found 502.1746 .

D-410643, an amorphous oil; ${ }^{1} \mathrm{H}-\mathrm{NMR}\left(500 \mathrm{MHz},{ }^{6} \mathrm{~d}-\right.$ acetone) $\delta$ : $1.74(\mathrm{~d}, \mathrm{~J}=7.6 \mathrm{~Hz}, 2 \mathrm{H}), 1.92(\mathrm{~d}, \mathrm{~J}=2.1 \mathrm{~Hz}$, $2 \mathrm{H}), 2.38(\mathrm{t}, \mathrm{J}=7.5 \mathrm{~Hz}, 2 \mathrm{H}), 3.02(\mathrm{t}, \mathrm{J}=7.5 \mathrm{~Hz}, 2 \mathrm{H})$, $7.087 .11(\mathrm{~m}, 1 \mathrm{H}), 7.177 .21(\mathrm{~m}, 2 \mathrm{H}), 7.257 .27(\mathrm{~m}, 1 \mathrm{H})$, $7.50(\mathrm{~d}, \mathrm{~J}=8.1 \mathrm{~Hz}, 1 \mathrm{H}), 7.67(\mathrm{~d}, \mathrm{~J}=7.8 \mathrm{~Hz}, 1 \mathrm{H}), 7.77(\mathrm{~d}$, $\mathrm{J}=2.4 \mathrm{~Hz}, 1 \mathrm{H}), 8.37(\mathrm{~d}, \mathrm{~J}=7.8 \mathrm{~Hz}, 1 \mathrm{H}), 8.83(\mathrm{~d}, \mathrm{~J}=3.0$ $\mathrm{Hz}, 1 \mathrm{H}), 10.66$ (br s, 1H),11.44 (br s, 1H). MS (ESI): $487.0\left(\mathrm{M}^{+}+\mathrm{H}\right)$; HREIMS: Calculated for $\mathrm{C}_{27} \mathrm{H}_{22} \mathrm{~N}_{2} \mathrm{O}_{7}\left(\mathrm{M}^{+}\right)$ 486.1427, found 486.1432 .

D-410644, an amorphous oil; ${ }^{1} \mathrm{H}-\mathrm{NMR}\left({ }^{6} \mathrm{~d}\right.$-acetone) $\delta$ : $3.25(\mathrm{t}, \mathrm{J}=7.0 \mathrm{~Hz}, 2 \mathrm{H}), 3.6(\mathrm{t}, \mathrm{J}=7.0 \mathrm{~Hz}, 2 \mathrm{H}), 7.09(\mathrm{~m}$, $1 \mathrm{H}), 7.17(\mathrm{~m}, 1 \mathrm{H}), 7.26(\mathrm{~m}, 2 \mathrm{H}), 7.50(\mathrm{~d}, \mathrm{~J}=8.1 \mathrm{~Hz}, 1 \mathrm{H})$, $7.67(\mathrm{~d}, \mathrm{~J}=8.0 \mathrm{~Hz}, 1 \mathrm{H}), 7.77(\mathrm{~d}, \mathrm{~J}=2.6 \mathrm{~Hz}, 1 \mathrm{H}), 8.39(\mathrm{~d}$, $\mathrm{J}=7.6 \mathrm{~Hz}, 1 \mathrm{H}), 8.85(\mathrm{~d}, \mathrm{~J}=3.1 \mathrm{~Hz}, 1 \mathrm{H}), 10.7$ (br s, 1H), 11.5 (br s, $1 \mathrm{H})$. MS (ESI): $459.0\left(\mathrm{M}^{+}+\mathrm{H}\right)$. HREIMS: Calculated for $\mathrm{C}_{25} \mathrm{H}_{18} \mathrm{~N}_{2} \mathrm{O}_{7}\left(\mathrm{M}^{+}\right)$458.1114, found 458.1109.

\section{Insulin Receptor Activation Assay}

The insulin receptor activation assay is based on the assay described by Zhang et al. [19-21] with minor modifica- 
tions. Briefly, approximately 100,000 CHO cells overexpressing human recombinant insulin receptor were suspended in $100 \mu \mathrm{l}$ of Ham's F-12 medium containing $10 \%$ fetal bovine serum (FBS) and seeded into each well of a 96-well plate. Cells were incubated at $37^{\circ} \mathrm{C}$ with $5 \%$ $\mathrm{CO}_{2}$ aeration overnight. CHO cells were rinsed with phosphate buffered saline (PBS) 3 times and starved in serum free Ham's F-12 medium for 2 hours before being stimulated with desired concentration of insulin or test compound for 20 minutes. Test compounds were predissolved in DMSO as $100 \times$ stocks and serially diluted when necessary. Stimulated CHO cells were then rinsed 3 times with PBS and lysed in $60 \mu \mathrm{l}$ of lysis buffer. Fifty $\mu$ l of the lysate was transferred to a well on a Flexible Assay Plate that was precoated with $\mathrm{Ab}-3$ antibody recognizing the $\beta$-subunit of insulin receptor. The well was then rinsed 3 times with Tris buffered saline (TBS) containing $0.1 \%$ Tween 20 and thrown dried by hand before $10 \mu \mathrm{l}$ of tyrosine kinase reaction mixture (50 mM HEPES, pH7.4, $5 \mathrm{mM} \mathrm{MgCl}_{2}, 5 \mathrm{mM}$ $\mathrm{MnCl}_{2}, 1 \mathrm{mg} / \mathrm{mL}$ polyGlu/Tyr and 250,000 cpm $\gamma$-P33 ATP/well) was added. The reaction was carried out at $25^{\circ} \mathrm{C}$ for 40 minutes and terminated by adding $50 \mu$ ice cold $100 \mathrm{mM}$ phosphoric acid. Fifty $\mu \mathrm{l}$ of the stopped reaction mixture was then transferred to an inch square P81 paper. The P81 paper was air dried and then rinsed in Millipore water 5 times to remove leftover radioactive ATP and product ADP. Five $\mathrm{mL}$ of scintillation cocktail was added to the paper before the count was read in a liquid scintillation counter.

\section{IGF-I Receptor Tyrosine Kinase Activity Assay}

The reaction was carried out at $\mathrm{pH} 7.0$ in the presence of $50 \mathrm{mM}$ HEPES, $5 \mathrm{mM} \mathrm{MgCl}_{2}, 0.01 \mu \mathrm{g} / \mu \mathrm{l}$ polyGlu/Tyr substrate, $5 \mathrm{mM}$ DTT, 250,000 cpm radioactive ATP, and 0.4 $\mathrm{ng} / \mu \mathrm{l}$ IGF-1R tyrosine kinase with a final volume of $100 \mu \mathrm{l}$ at $37^{\circ} \mathrm{C}$ for 10 minutes. The IGF- 1 receptor tyrosine kinase reaction was carried out with subsaturating concentrations of substrates for better sensitivity to activator or inhibitor influence. Test compound D-410639 was predissolved in DMSO as $20 \times$ stock. The reaction was stopped by the addition of $100 \mu \mathrm{l}$ of $25 \mathrm{mM}$ EDTA (pH8), and $85 \mu \mathrm{l}$ of the stopped reaction mix was blotted on an inch square P81 paper. P81 paper was air dried before rinsed 5 times in Millipore water to remove non-protein phosphorus. Five mL scintillation cocktail was added to the P81 paper before the counts were read with a liquid scintillation counter.

\section{EGF Receptor (ErbBI) Tyrosine Kinase Activity Assay}

The reaction condition of EGF receptor (ErbB1) was similar to that of IGF-1 receptor reaction except $0.04 \mu \mathrm{g} / \mu \mathrm{l}$ polyGlu/Tyr substrate and $0.3 \mathrm{ng} / \mu \mathrm{l}$ EGF receptor (ErbB1) were used, and the reaction time was 15 minutes. All other conditions or processes were the same. The EGF receptor tyrosine kinase reaction was carried out with subsaturat- ing concentrations of substrates for better sensitivity to activator or inhibitor influence.

\section{FGF Receptor 3 Tyrosine Kinase Activity Assay}

The reaction condition of FGF receptor 3 was similar to that of EGF receptor except $0.1 \mu \mathrm{g} / \mu \mathrm{l}$ polyGlu/Tyr substrate and $0.05 \mathrm{ng} / \mu \mathrm{l}$ FGF-receptor 3 were used instead. All other conditions or processes were the same. The FGF receptor 3 tyrosine kinase reaction was carried out with subsaturating concentrations of substrates for better sensitivity to activator or inhibitor influence.

\section{Cytotoxicity Assay}

Approximately 5,000 CHO cells suspended in $100 \mu \mathrm{l}$ MEM containing 10\% FBS were seeded in each well of a 96-well plate overnight before the cytotoxicity assay. Test compounds were predissolved as $10 \times$ solution in $10 \%$ DMSO, $10 \%$ ethanol, $80 \%$ PBS and $10 \mu \mathrm{l}$ of this $10 \times$ test compound solution were added to each well. After 24 hours incubation, medium containing test compound was removed by aspiration and 3 rinses of PBS. One hundred $\mu \mathrm{l}$ of serum medium was replenished before $20 \mu \mathrm{l}$ methylthiazolyldiphenyl-tetrazolium bromide (MTT, 2.5 $\mathrm{mg} / \mathrm{mL}$ ) and $1 \mu \mathrm{l}$ phenazine methosulfate (PMS, $50 \mu \mathrm{M}$ ) was added to each well before a 3-hour further incubation at $37^{\circ} \mathrm{C}$. Optical density at $450 \mathrm{~nm}$ was measured with an ELISA reader. $\mathrm{LC}_{50}$ is defined as the concentration of compound that causes 50\% drop of cell viability in this test.

\section{Determination of $E C_{50}$ or I $C_{50}$}

The 50\% effective or inhibition concentrations were determined with the standard curve analysis of SigmaPlot 8.02. The nonlinear regression equation is $\mathrm{y}=\min +(\max -\min ) /$ $\left(1+\left(\mathrm{x} / \mathrm{EC}_{50}\right)^{\text {Hill Slope }}\right)$ where $\mathrm{y}$ is the observed responses; $\mathrm{x}$ is the dose concentrations; max and min are approximated by the program automatically during the calculation.

\section{Results}

\section{Insulin receptor tyrosine kinase activation}

To validate the insulin receptor activation assay, dose response curve of bovine insulin was determined. The $\mathrm{EC}_{50}$ of bovine insulin is approximately $5.1 \mathrm{nM}$, which is reasonable comparing to $1 \mathrm{nM}$ reported by Liu et al. [21]. In subsequent experiments, we routinely included 1, 10, and $100 \mathrm{nM}$ insulin as standard reference. Since $10 \mathrm{nM}$ insulin showed more consistent potency, we chose $10 \mathrm{nM}$ insulin as the standard concentration serving as a reference point for all experiments. For simplicity, the efficacies of hydroxyfuroic acid compounds were expressed as percentage of activities comparing to the response provided by $10 \mathrm{nM}$ insulin stimulation in parallel. To distinguish human insulin receptor kinase from other tyrosine kinases in $\mathrm{CHO}$ cells, $\mathrm{Ab}-3$, a human insulin receptor $\beta$ subunit specific monoclonal antibody, was used to absorb 
insulin receptor from the $\mathrm{CHO}$ cell lysate, so the radioactivity catalyzed by captured tyrosine kinase is attributable to insulin receptor tyrosine kinase activity.

\section{Non-quinone hydroxyfuroic acid as insulin receptor activator}

Various hydroxyalkyl side chains were derived to test the best structure on the 7-indolyl position. Hydroxyl or carboxyl derivatives of 3-carbon or longer side chain showed sustained insulin receptor activation potential (Table 1). A side chain of 5-carbon alcohol showed better efficacy (D-410639, 7289\%) over 4- or 3- carbon alcohol derivatives (D-410638, 31.3\%; D-410637, 18.9\%, respectively). The hydroxyl group is important because its non-hydroxyl counterpart (D-410641) achieved only $48.6 \%$ efficacy. One additional hydroxymethyl side chain (D-410642) does not help the efficacy, since it remains low at $40.4 \%$; nor oxidation of the hydroxyl group to a carboxyl group, because it offers no substantial improvement to the efficacies (D-410643, 48.9\%; D-410644, 21.9\%, respectively). Therefore, a 5-carbon hydroxypentyl side chain on the 7 indolyl position offers the best insulin receptor activation efficacy thus far, and consistently we have observed highest receptor responses associated with D-410639 stimulation when compared to other compounds in multiple occasions (data not shown).

In a separate experiment, the potency of D-410639 was compared to that of compound 2, as shown in Fig. 3. In this assay, the maximal activity of either compound reached $6670 \%$ of receptor kinase activation provided by $10 \mathrm{nM}$ insulin and the $\mathrm{EC}_{50}$ are 33 and $39 \mu \mathrm{M}$ for D410639 and compound 2, respectively. The $\mathrm{EC}_{50}$ for compound 2 is about 2-order different from $0.3 \mu \mathrm{M}$ reported previously by Merck's group [20,21]. The exact reason for this discrepancy is not clear, as our compound 2 was also obtained from Merck, however, a logical explanation is that different laboratory practice resulted in different out- comes but under identical conditions, D-410639 is as potent as compound 2.

D-410640 is a thiophene equivalent of D-410639, with a higher yield advantage during the synthesis process, so its efficacy on insulin receptor activation was examined. Unfortunately, the efficacy of D-410640 levels off at 50 $\mu \mathrm{M}$ and tapers off by $100 \mu \mathrm{M}$, suggesting a negative effect associated with the thiophene moiety at mid to high $\mu \mathrm{M}$ range. As a result, thiophene derivatives were not pursued further (Fig. 4).

\section{Cytotoxicity and growth factor receptor selectivity of D- 410639}

Because D-410639 is a non-quinone derivative, its cytotoxicity against quinone derivatives, i.e., DMAQ B1 and compound 2, on Chinese hamster ovary ( $\mathrm{CHO}$ ) tissue cell culture were examined. DMAQ B1 showed the strongest cytotoxic effect $\left(\mathrm{LC}_{50}=2.3 \mu \mathrm{M}\right)$, while compound 2 improved the cytotoxicity to $66.5 \mu \mathrm{M}$. As one may expect, D-410639 further alleviated the cytotoxicity to approximately $296 \mu \mathrm{M}$, attributable to the replacement of the dihydroxyquinone moiety with a hydroxyfuroic acid moiety (Fig. 5).

Asterriquinone are known for its potential to activate insulin-like growth factor-1 (IGF-1) and epidermal growth factor (EGF) receptors at mid to high $\mu \mathrm{M}$ range $[19,22]$; therefore, it is important to characterize D410639 's activation potential at these growth factor receptors. The IGF-1 receptor activity was increased by about $6070 \%$ from the base line with mid $\mu \mathrm{M}$ of D-410639 (Fig. $6 \mathrm{~A})$ and the non-linear $\mathrm{EC}_{50}$ fitting curve program suggested $\mathrm{EC}_{50}$ to be $17 \mu \mathrm{M}$, but the statistical t-test of the $\mathrm{EC}_{50}$ itself is not significant $(\mathrm{p}=0.63)$ due to large variation.

Unlike the minor activation potential of DMAQ-B1 on EGF receptor (ErbB1) as reported by Zhang et al. [19], D-

Table I: Relative insulin receptor activation potentials of hydroxyfuroic acid compounds with various prenylindole moiety.

\begin{tabular}{|c|c|c|c|c|c|}
\hline Compound & Side Chain & Study Ia & $\%$ activation ${ }^{b}$ & Study $2^{\mathrm{a}}$ & $\%$ activation ${ }^{b}$ \\
\hline$D-410637$ & $\left(\mathrm{CH}_{2}\right)_{2} \mathrm{CH}_{2} \mathrm{OH}$ & 18.9 & & & \\
\hline D-410638 & $\left(\mathrm{CH}_{2}\right)_{3} \mathrm{CH}_{2} \mathrm{OH}$ & 31.3 & & & \\
\hline D-410639 & $\left(\mathrm{CH}_{2}\right)_{4} \mathrm{CH}_{2} \mathrm{OH}$ & 5590 & 89.4 & 1181 & 72.3 \\
\hline$D-41064 \mid$ & $\left(\mathrm{CH}_{2}\right)_{4} \mathrm{CH}_{3}$ & & & 792.7 & 48.6 \\
\hline D-410642 & $\left(\mathrm{CH}_{2}\right)_{3} \mathrm{CH}\left(\mathrm{CH}_{2} \mathrm{OH}\right)_{2}$ & & & 659.3 & 40.4 \\
\hline D-410643 & $\left(\mathrm{CH}_{2}\right)_{4} \mathrm{COOH}$ & & & 799 & 48.9 \\
\hline D-4I0644 & $\left(\mathrm{CH}_{2}\right)_{2} \mathrm{COOH}$ & & & 357.3 & 21.9 \\
\hline Insulin $10 \mathrm{nM}$ & & 6250 & & 1632.5 & \\
\hline
\end{tabular}

a Data in these columns are cpm, representing phosphoryl incorporation by tyrosine kinase activities. Study I and 2 are separate experiments each with a $10 \mathrm{nM}$ insulin and a $100 \mu \mathrm{M}$ D-410639 control for internal reference. The test concentration for hydroxyfuroic acid compounds was $100 \mu \mathrm{M}$. See Materials and Methods for detail.

${ }^{b}$ Percentage of tyrosine kinase activities as compared to that offered by $10 \mathrm{nM}$ insulin stimulation, presented at the bottom row. 


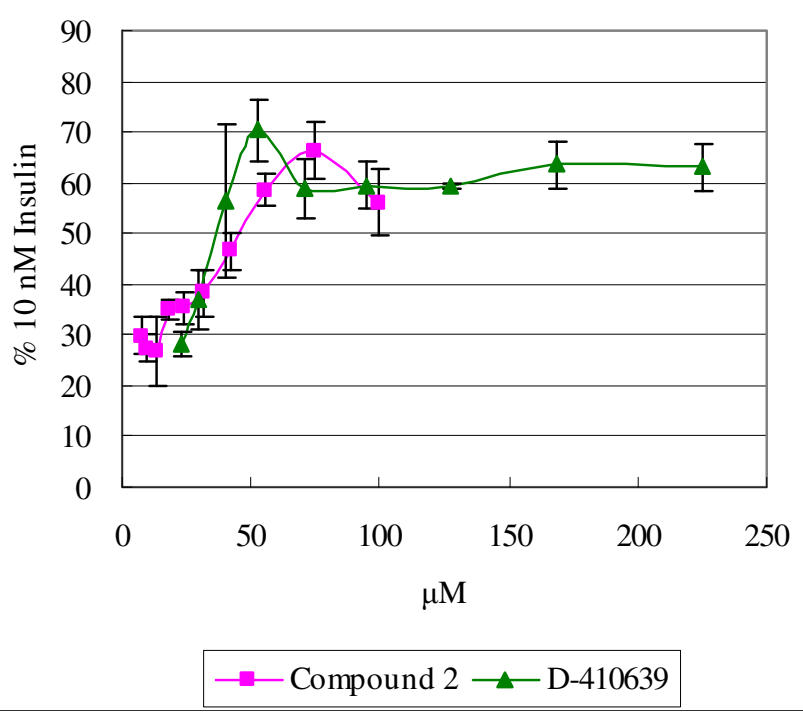

Figure 3 Insulin receptor tyrosine kinase activation curves by compound D-410639 and compound 2. The activation assays were determined side by side, and both compounds plateau out at about $60 \%$ level achieved by $10 \mathrm{nM}$ insulin with $\mathrm{EC}_{50}$ being $32.9 \mu \mathrm{M}$ for D-410639 and $38.9 \mu \mathrm{M}$ for compound 2. Error bars indicate standard deviations.

410639 demonstrated a substantial inhibitory property on EGF-R (ErbB1) tyrosine kinase activity, with the $\mathrm{IC}_{50}$ being estimated to be $1.8 \mu \mathrm{M}$ (Fig. 6B). Interestingly, D410639 is also an effective inhibitor on fibroblast growth factor (FGF) receptor 3 tyrosine kinase with the $\mathrm{IC}_{50}$ projected at $26.5 \mu \mathrm{M}$ (Fig. 6C).

\section{Discussion}

This study presents a new class of insulin receptor activator, compounds with a hydroxyfuroic acid scaffold, which, along with DMAQ B1 and Merck's compound 2, can activate insulin receptor in the absence of insulin. In contrast to the report by Wood et al. [27], we found the dihydroxyquinone moiety is replaceable by a hydroxyfuroic acid moiety without losing much of the insulin receptor activation capability (Fig. 3). At the meantime, without a dihydroxyquinone moiety, the cytotoxicity effect of insulin receptor activator on $\mathrm{CHO}$ cells was reduced by 128 fold (Fig. 5) as compared to DMAQ B1.

Perhaps the most intriguing part of these new insulin receptor activators is that dihydroxyquinone derivatives can tolerate the replacement of isoprenylindole by a phenyl group so well that compound 2 of Merck has an even better efficacy than original DMAQ B1 [20,21]. However, the same does not apply to hydroxyfuroic acid compounds; a phenyl substitution for the isoprenylindole on a hydroxyfuroic acid compound renders these com- pounds inactive completely. That is, DMAQ B1 may be transformed to a hydroxyfuroic acid derivative or simplified to compound 2 (phenylindolylhydroxyquinone) and retains its insulin receptor activation potential, but these two features cannot be combined together (Fig 2). The reason for this incompatibility may be too difficult to be demonstrated by the medicinal chemistry approach; perhaps X-ray crystallography of these compounds with an insulin receptor may have a better chance of answering this question. Despite insulin receptor tyrosine kinase domain structure has been solved long ago [28] and the activation mechanism is well studied [29], the exact binding pocket for DMAQ B1 on insulin receptor remains unknown. Though this site has been postulated [30], how does the binding of an insulin receptor activator compound trigger receptor tyrosine kinase activation remains to be illustrated.

The prenylindole moiety is important for bioactivities of asterriquinone and compounds with a hydroxyfuroic acid scaffold (Table 1), because: i) diisoprenylindolylasterriquinone (L-767827 in ref. [19]) showed no insulin receptor tyrosine kinase activation potential; ii) in a series of test compounds (D-410637, D-410638 and D-410639), the compound's efficacy is dictated by the length of the hydroxyalkyl chain, which is an oxidized derivative of the prenyl chain. Presumably, this alkyl side chain may have a corresponding binding pocket on the insulin receptor, and the pocket is probably hydrophobic in nature because pentanol (D-410639) or pentyl (D-410641) side chains are both well accommodated while shorter butanol (D410638) or propanol (D-410637) side chains are well tolerated but with lower efficacies. At the distal end of this side chain pocket, insulin receptor prefers one hydroxyl group because the activity improves with the addition of a hydroxyl group on the pentyl chain, but the addition of a second hydroxymethyl group (D-410642) or oxidation of the terminal alcohol group to a carboxyl group (D410643) offers no improvement. Therefore, a hydrophilic group and potentially a hydrogen bond donor or acceptor is likely preferred at the distal end of this pocket. However, compound 2 of Merck is a noticeable exception which does not have a prenyl or an alkyl chain on its methylindole moiety. How does compound 2 activate insulin receptor tyrosine kinase without a 7-prenyl or 7alkyl chain remains to be illustrated.

The exact nature or importance of the isoprenyl chain on DMAQ B1 is not known, since we did not have any compound for direct comparison. But the isoprenylindole moiety can be simplified to an indole and still retains significant activity (D-410639 and all other compounds listed in Table 1), suggesting it is not essential for insulin receptor activation with a hydroxyfuroic acid as the scaffold. If this assumption is false, all those hydroxyfuroic 

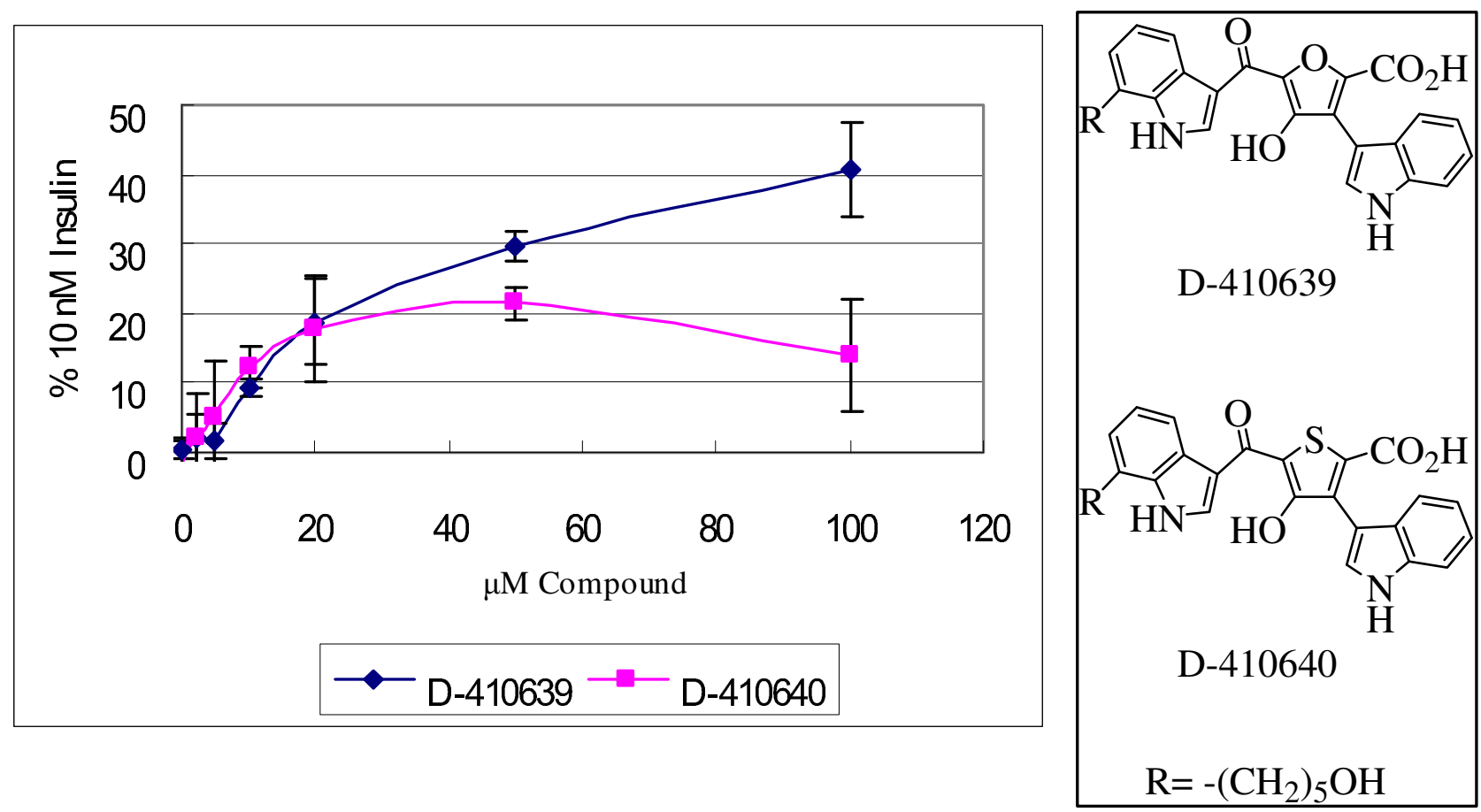

Figure 4

Dose response curves of compound D-4 10639 and D-4 I 0640 . Receptor tyrosine kinase activation was normalized against $10 \mathrm{nM}$ insulin activation. Each curve is an average of 3 determinations and the error bars indicate standard deviations.

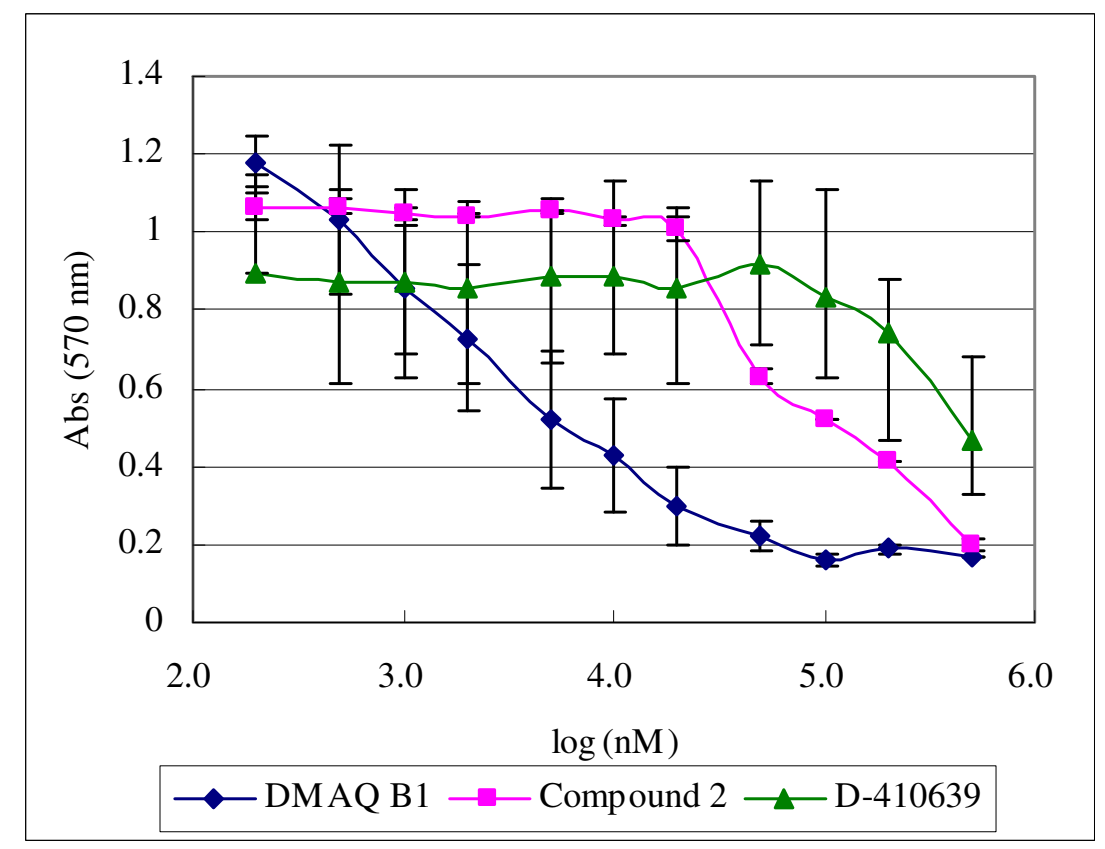

\section{Figure 5}

Cytotoxicity test of DMAQ-B I, compound 2 and D-4 10639 on CHO cells. CHO cells were treated with various concentrations of test compounds and their viability was measured with the use of MTT. LC ${ }_{50}$ for DMAQ-BI, compound 2, and D410639 are $2.3 \mu \mathrm{M}, 66.5 \mu \mathrm{M}$, and $295.9 \mu \mathrm{M}$, respectively. Error bars indicate standard error of the mean (SEM). See Materials and Methods for detail. 
A. IGF-1Receptor Response

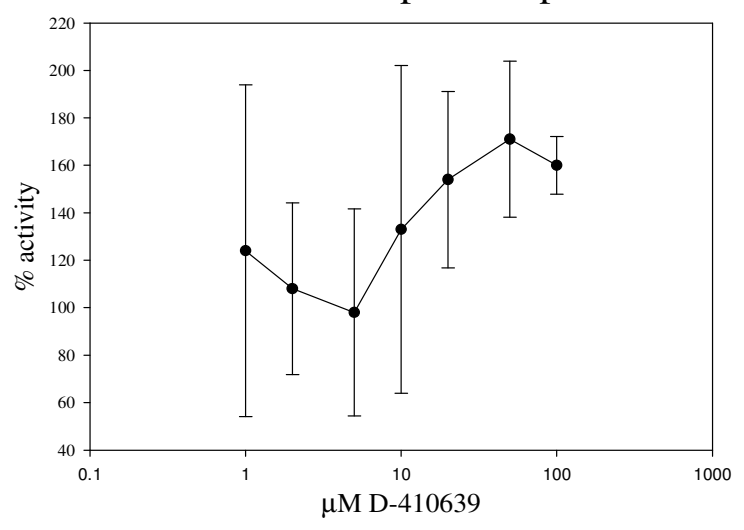

B. EGF Receptor (ErbB1) Response

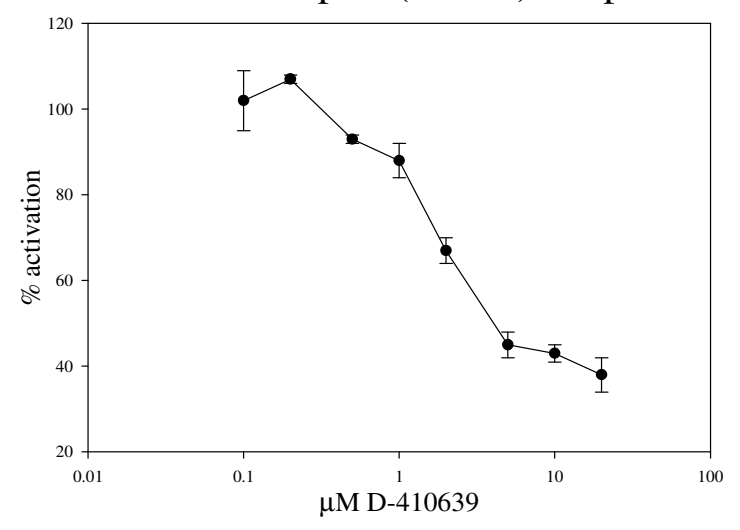

C. FGF Receptor 3 Response

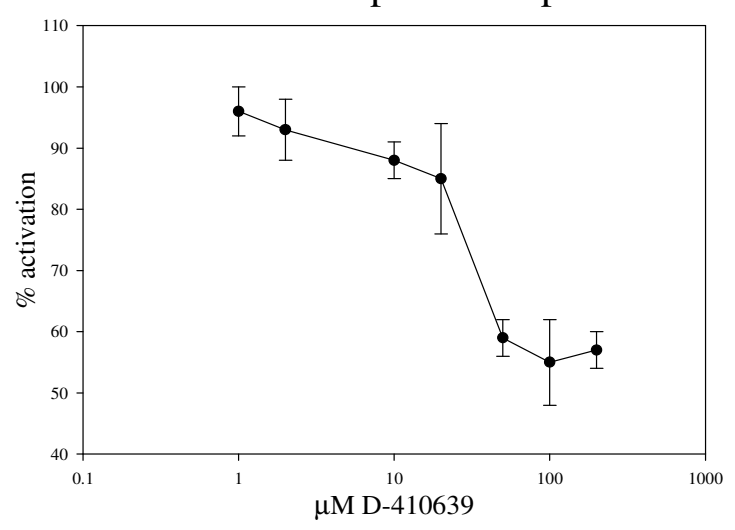

Figure 6

Dose effect of compound D-4 I 0639 on the tyrosine kinase activities of IGF-I receptor (panel A), EGF receptor (ErbB I, panel B), and FGF receptor 3 (panel C). Receptor tyrosine kinase activation was compared to the control which received a blank placebo, and the base line control was considered as $100 \%$ activity. Error bars indicate standard deviations.

Projected $\mathrm{EC}_{50}$ for IGF-I receptor was $16.9 \mu \mathrm{M}$, but the $\mathrm{EC}_{50}$ is not statistically significant. The IC ${ }_{50}$ for EGF receptor (ErbBI) and FGF receptor 3 are $1.8 \mu \mathrm{M}$ and $26.5 \mu \mathrm{M}$, respectively. See Materials and Methods for detail. 
acid compounds in Table 1 would have shown no activity essentially. Therefore, it is suggested that isoprenyl group is not likely to play a significant role as other features at activating insulinreceptor.

Another interesting aspect of D-410639 is its inhibitory potential at epidermal growth factor receptor. Studies have shown that EGF signal plays a major role at the development of vascular dysfunction in diabetic animals $[31,32]$, and thus inhibition of EGF receptor in diabetic subjects may be useful at alleviating vascular complication associated with the hyperglycemic condition [33]. Therefore, a dual function compound like D-410639 with dual properties, activator for insulin receptor and antagonist for EGF receptor, is rather interesting and deserves further study.

\section{Abbreviations}

CHO: Chinese hamster ovary; DDQ: 2,3-dichloro-5,6dicyano-p-benzoquinone; DMAP: 4-dimethylaminopyridine; DMAQ B1: demethylasterriquinone B1; DMF: $N, N$ dimethylformamide; D-MEM: Dulbecco's modified Eagle's medium; DMSO: dimethylsulfoxide; EGF: epidermal growth factor; FBS: fetal bovine serum; FGF: fibroblast growth factor; HRMS: high resolution mass spectrometry; IGF-1: insulin-like growth factor-1; MTT: methylthiazolyldiphenyl-tetrazolium bromide; MS: mass spectrometry; PBS: phosphate buffered saline; PMS: phenazine methosulfate; TBS: tris buffered saline.

\section{Competing interests}

The authors declare that they have no competing interests.

\section{Authors' contributions}

HJT is responsible for biological assays; SYC is responsible for chemical syntheses.

\section{Acknowledgements}

This study was supported by Ministry of Economic Affairs, Taiwan. The authors would like to express sincere gratitude to Drs. Tom Chen and Lee Huang for their suggestions to this research project; Hong Liu, Arthur Yang, and Kenny Chen for their diligent work to make this project possible.

\section{References}

I. Ross SA, Gulve EA, Wang M: Chemistry and biochemistry of type 2 diabetes. Chem Rev 2004, I 04(3): I 255-I 282.

2. Gale EA: The discovery of type I diabetes. Diabetes 200I, 50(2):217-226.

3. Zhou G, Myers R, Li Y, Chen Y, Shen X, Fenyk-Melody J, Wu M, Ventre J, Doebber T, Fujii N, Musi N, Hirshman MF, Goodyear LJ, Moller DE: Role of AMP-activated protein kinase in mechanism of metformin action. J Clin Invest 200।, I08(8): I I67-I I74.

4. Winder WW, Thomson DM: Cellular energy sensing and signaling by AMP-activated protein kinase. Cell Biochem Biophys 2007, 47(3):332-347.

5. Towler MC, Hardie DG: AMP-activated protein kinase in metabolic control and insulin signaling. Circ Res 2007, I 00(3):328-34I.

6. Kemp BE, Stapleton D, Campbell DJ, Chen ZP, Murthy S, Walter M, Gupta A, Adams JJ, Katsis F, van Denderen B, Jennings IG, Iseli T,
Michell BJ, Witters LA: AMP-activated protein kinase, super metabolic regulator. Biochem Soc Trans 2003, 31:162-168.

7. Ashcroft FM: ATP-sensitive potassium channelopathies: focus on insulin secretion. J Clin Invest 2005, I I 5(8):2047-2058.

8. Zünkler BJ: Human ether-a-go-go-related (HERG) gene and ATP-sensitive potassium channels as targets for adverse drug effects. Pharmacol Ther 2006, I I 2(I): I2-37.

9. Bryan J, Crane A, Vila-Carriles WH, Babenko AP, Aguilar-Bryan L: Insulin secretagogues, sulfonylurea receptors and K(ATP) channels. Curr Pharm Des 2005, I I(2I):2699-27I6.

10. Lee $\mathrm{CH}$, Olson P, Evans RM: Minireview: lipid metabolism, metabolic diseases, and peroxisome proliferator-activated receptors. Endocrinology 2003, I44(6):220I-2207.

II. Bhatia V, Viswanathan P: Insulin resistance and PPAR insulin sensitizers. Curr Opin Investig Drugs 2006, 7( I 0):891-897.

12. Boden $G$, Zhang M: Recent findings concerning thiazolidinediones in the treatment of diabetes. Expert Opin Investig Drugs 2006, I 5(3):243-250.

13. Josse RG, McGuire AJ, Saal GB: A review of the economic evidence for acarbose in the prevention of diabetes and cardiovascular events in individuals with impaired glucose tolerance. Int J Clin Pract 2006, 60(7):847-855.

14. Hanefeld M: Cardiovascular benefits and safety profile of acarbose therapy in prediabetes and established type 2 diabetes. Cardiovasc Diabetol 2007, 6:20-29.

15. Tsai HJ, Chou SY, Chuang SH, Chen CC, Hsu FL: D-42 A Novel Orally Active Sulfonamide Compound Dipeptidyl Peptidase IV Inhibitor: Structure and Activity Relationship of Arylsulfonamide to DipeptidyI Peptidase IV Inhibition. Drug Develop Res 0720, 69:514-519.

16. Holst JJ, Deacon CF: Inhibition of the activity of dipeptidylpeptidase IV as a treatment for type 2 diabetes. Diabetes 1998, 47(I I): I663-I670.

17. Conarello SL, Li Z, Ronan J, Roy RS, Zhu L, Jiang G, Liu F, Woods J, Zycband E, Moller DE, Thornberry NA, Zhang BB: Mice lacking dipeptidyl peptidase IV are protected against obesity and insulin resistance. Proc Natl Acad Sci USA 2003, I 00( I I ):6825-6830.

18. Weber AE: Dipeptidyl peptidase IV inhibitors for the treatment of diabetes. J Med Chem 2004, 47(I 7):4I35-4I4I.

19. Zhang B, Salituro G, Szalkowski D, Li Z, Zhang Y, Royo I, Vilella D, Diez MT, Pelaez F, Ruby C, Kendall RL, Mao X, Griffin P, Calaycay J, Zierath JR, Heck JV, Smith RG, Moller DE: Discovery of a small molecule insulin mimetic with antidiabetic activity in mice. Science 1999, 284(54 16):974-977.

20. Qureshi SA, Ding V, Li Z, Szalkowski D, Biazzo-Ashnault DE, Xie D, Saperstein R, Brady E, Huskey S, Shen X, Liu K, Xu L, Salituro GM, Heck JV, Moller DE, Jones AB, Zhang BB: Activation of insulin signal transduction pathway and anti-diabetic activity of small molecule insulin receptor activators. J Biol Chem 2000, 275(47):36590-36595.

21. Liu K, Xu L, Szalkowski D, Li Z, Ding V, Kwei G, Huskey S, Moller DE, Heck JV, Zhang BB, Jones AB: Discovery of a potent, highly selective, and orally efficacious small-molecule activator of the insulin receptor. J Med Chem 2000, 43(19):3487-3494.

22. Salituro GM, Pelaez F, Zhang BB: Discovery of a small molecule insulin receptor activator. Recent Prog Horm Res 200I, 56:107-126.

23. Ding VD, Qureshi SA, Szalkowski D, Li Z, Biazzo-Ashnault DE, Xie D, Liu K, Jones AB, Moller DE, Zhang BB: Regulation of insulin signal transduction pathway by a small-molecule insulin receptor activator. Biochem J 2002, 367:30I-306.

24. Strowski MZ, Li Z, Szalkowski D, Shen X, Guan XM, Juttner S, Moller $\mathrm{DE}$, Zhang BB: Small molecule insulin mimetic reduces hyperglycemia and obesity in a non-genetic mouse model of type 2 diabetes. Endocrinology 2004, I 45(I I):5259-5268.

25. Wang X, Thomas B, Sachdeva R, Arterburn L, Frye L, Hatcher PG, Cornwell DG, Ma J: Mechanism of arylating quinone toxicity involving Michael adduct formation and induction of endoplasmic reticulum stress. Proc Natl Acad Sci USA 2006, I03( I 0):3604-3609.

26. Chou SY, Chen SST, Chen CH, Chang LS: Regioselective synthesis of 3-aryl-5-( I H-indole-3-carbonyl)-4-hydroxyfuroic acids as potential insulin receptor activators. Tetrahedron Lett 2006, 47(43):7579-7582. 
27. Wood HB, Black R, Salituro G, Szalkowski D, Li Z, Zhang Y, Moller $D E$, Zhang $B$, Jones $A B$ : The basal SAR of a novel insulin receptor activator. Bioorg Med Chem Lett 2000, I O(I I): I I 89-II 92.

28. Hubbard SR, Wei L, Ellis L, Hendrickson WA: Crystal structure of the tyrosine kinase domain of the human insulin receptor. Nature 1994, 372(6508):746-754.

29. Hubbard SR: Crystal structure of the activated insulin receptor tyrosine kinase in complex with peptide substrate and ATP analog. EMBO J 1997, I6( 18):5572-558I.

30. Li S, Covino ND, Stein EG, Till JH, Hubbard SR: Structural and biochemical evidence for an autoinhibitory role for tyrosine 984 in the juxtamembrane region of the insulin receptor. J Biol Chem 2003, 278(28):26007-260I4.

31. Nishinaka T, Yabe-Nishimura C: EGF receptor-ERK pathway is the major signaling pathway that mediates upregulation of aldose reductase expression under oxidative stress. Free Radic Biol Med 200I, 3 I (2):205-2I6.

32. Benter IF, Yousif MH, Hollins AJ, Griffiths SM, Akhtar S: Diabetesinduced renal vascular dysfunction is normalized by inhibition of epidermal growth factor receptor tyrosine kinase. J Vasc Res 2005, 42(4):284-9I.

33. Belmadani S, Palen DI, Gonzalez-Villalobos RA, Boulares HA, Matrougui K: Elevated Epidermal Growth Factor Receptor Phosphorylation Induces Resistance Artery Dysfunction in Diabetic db/db mice. Diabetes 2008, 57(6):1629-1637.

Publish with Bio Med Central and every scientist can read your work free of charge

"BioMed Central will be the most significant development for disseminating the results of biomedical research in our lifetime. "

Sir Paul Nurse, Cancer Research UK

Your research papers will be:

- available free of charge to the entire biomedical community

- peer reviewed and published immediately upon acceptance

- cited in PubMed and archived on PubMed Central

- yours - you keep the copyright

Submit your manuscript here:

http://www.biomedcentral.com/info/publishing_adv.asp
BiolMedcentral 